\title{
Wind Energy Map of Arabian Gulf
}

\author{
Khaled Al-Salem ${ }^{1}$, Subramaniam Neelamani ${ }^{1}$, Waleed Al-Nassar ${ }^{2}$ \\ ${ }^{1}$ Coastal Management Program, Environment and Life Sciences Research Center, Shuwaikh, Kuwait \\ ${ }^{2}$ Renewable Energy Program, Energy and Building Research Centre, Shuwaikh, Kuwait \\ Email:ksalem@kisr.edu.kw,nsubram@kisr.edu.kw,wnassar@kisr.edu.kw
}

How to cite this paper: Al-Salem, K., Neelamani, S. and Al-Nassar, W. (2018) Wind Energy Map of Arabian Gulf. Natural Resources, 9, 212-228. https://doi.org/10.4236/nr.2018.95014

Received: April 2, 2018

Accepted: May 28, 2018

Published: May 31, 2018

Copyright $\odot 2018$ by authors and Scientific Research Publishing Inc. This work is licensed under the Creative Commons Attribution International License (CC BY 4.0).

http://creativecommons.org/licenses/by/4.0/

(c) (i) Open Access

\begin{abstract}
Wind power is not only pollution free and renewable but is becoming more economical with technology development. The countries around the Arabian Gulf region are investing for wind powers both the land and in their marine space. A detailed study on wind power resource in the Arabian Gulf is not available. This paper is on the wind energy resource availability over Arabian Gulf waters, covering 2300 grid points. The data available with Coastal Information System data base at Kuwait Institute for Scientific Research, Kuwait, from 1979 to 2015 is used. The probability density and power density were derived from these data source. Weibull probability density function has been fitted to the wind speed data and the wind power density was evaluated. The study is carried out at $10 \mathrm{~m}, 30 \mathrm{~m}$ and $50 \mathrm{~m}$ elevations. The central location of the Arabian Gulf has higher annual average wind speed, ranging from 6 to 8 $\mathrm{m} / \mathrm{s}$ at $10 \mathrm{~m}$ elevation, 7 to $8 \mathrm{~m} / \mathrm{s}$ at $30 \mathrm{~m}$ elevation and 8 to $9 \mathrm{~m} / \mathrm{s}$ at $50 \mathrm{~m}$ elevation. The scale parameter " $c$ " at central location of Arabian Gulf is found to range from $6-8 \mathrm{~m} / \mathrm{s}$ for $10 \mathrm{~m}$ elevation, $7-8 \mathrm{~m} / \mathrm{s}$ for $30 \mathrm{~m}$ elevation and $8-9$ $\mathrm{m} / \mathrm{s}$ for $50 \mathrm{~m}$ above sea level. The Weibull shape parameter $\mathrm{k}$ varies from 2.5 to 3 at the north and central of the Arabian Gulf. The annual mean wind power density over Arabian Gulf Waters is the highest in the central region of the Gulf. The power density at $10 \mathrm{~m}, 30 \mathrm{~m}$ and $50 \mathrm{~m}$ hub height varies between 200 to $300 \mathrm{w} / \mathrm{m}^{2}, 200$ to $300 \mathrm{w} / \mathrm{m}^{2}$ and more than $300 \mathrm{w} / \mathrm{m}^{2}$ respectively. It is attractive to install large scale wind power generation at the central region of the Arabian Gulf and at elevations of $30 \mathrm{~m}$ or $50 \mathrm{~m}$, since this region lies in Class 2 category of the Wind Energy Resource Atlas of the United States. The wind power density is attractive especially in summer season around the central region location in Arabian Gulf (Saudi Arabia, Bahrain and Qatar), since high rate of power is used for air conditioning systems in summer.
\end{abstract}

\section{Keywords}

Wind Energy, Arabian Gulf, Weibull Distribution, Gulf Cooperation Council, Kuwait 


\section{Introduction}

Arabian Gulf is one of the promising seas in the Middle East and is located in between Saudi Arabia on its west and Iran on its east (Figure 1). The Arabian Gulf is surrounded by Oman, Saudi Arabia, UAE, Qatar, Bahrain, Kuwait, Iraq and Iran. The Gulf is known for its rich source of oil and gas, which is being very effectively exploited by most of the countries. The gulf has a few islands and there are a plenty of large developed cities located on its shores. The water depth of the Arabian Gulf is shallow. Water depths of more than $100 \mathrm{~m}$ are available only on the Iranian coast.

The countries surrounding the Arabian Gulf generate power mainly from hydrocarbons like oil and gas. Though hydrocarbon-based fuel can provide the needed energy in the future, the Gulf Cooperation Council (GCC) Countries have proposed targets for renewable energy (Figure 2).

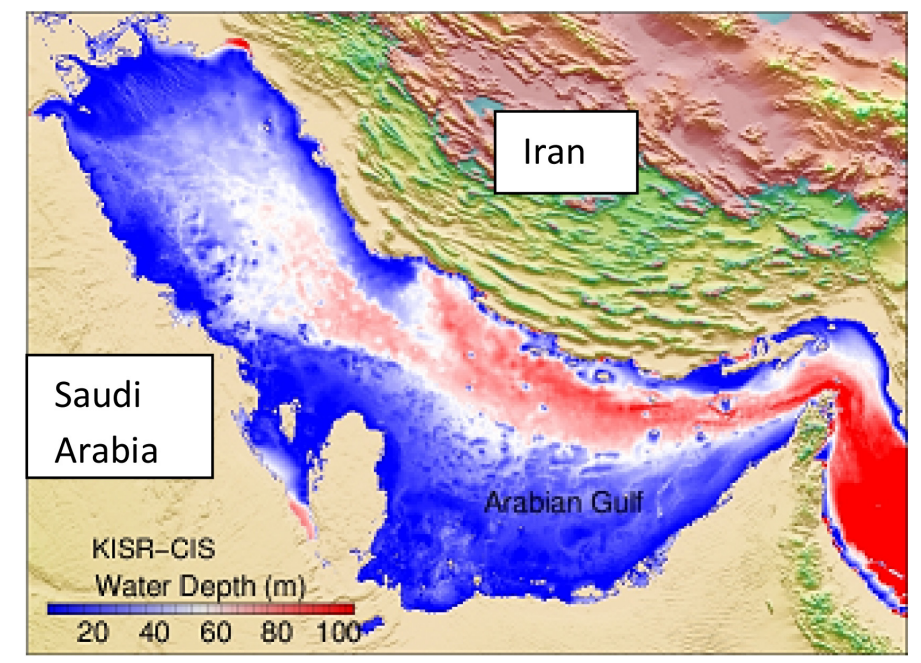

Figure 1. Arabian gulf and its bathymetry.

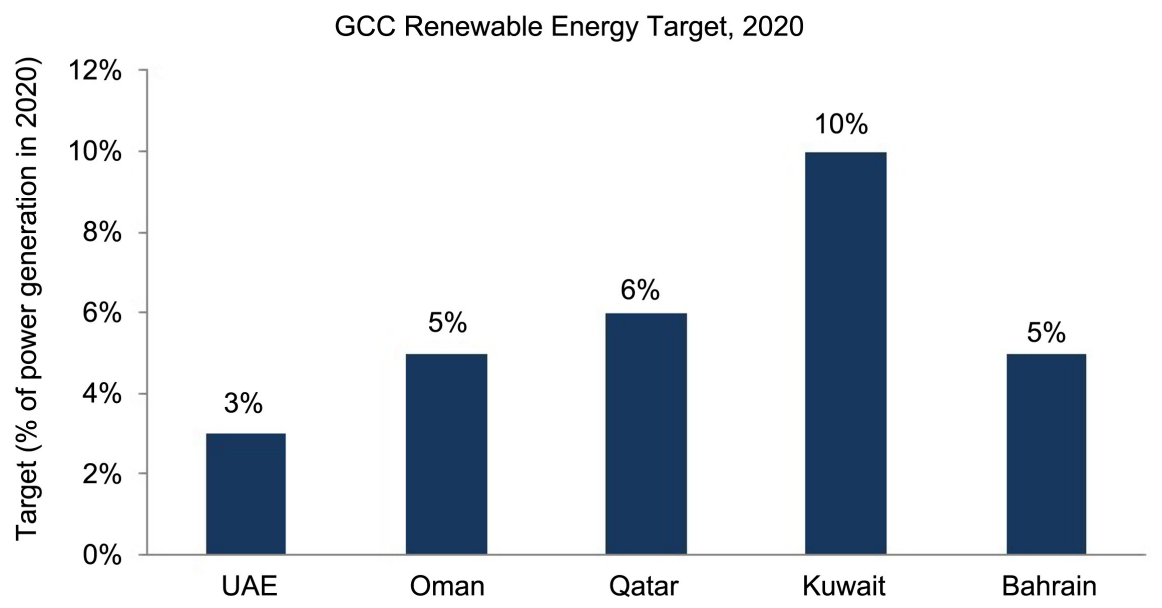

Figure 2. Renewable energy target in GCC countries by the year 2020 (Source: https://www.e-marmore.com/Blog/Infrastructure/March-2015/Alternative-Energy-in-Fos sil-Fuel-Rich-GCC-Countries). 
A study by apricum group

(https://www.apricum-group.com/gcc-countries-rising-stars-solar-wind/\#_ftn1) reveals that wind power may be cheaper than oil based power, if the real export cost is considered for oil. For example, apricum group revealed that solar and wind power can effectively complement the existing conventional capacity and provide electricity at low cost of below 10 USD cent $/ \mathrm{kWh}$-about half the cost of oil-fired power generation at market prices. In fact, the most recent tender in Dubai has resulted in the remarkable tariff of 6 USD cent/kWh (unsubsidized). So, particularly oil-rich countries such as Saudi Arabia, Kuwait or the United Arab Emirates (UAE) are better off exporting oil instead of burning it domestically for power generation.

In general, GCC countries have an abundant source of oil and gas and hence at the beginning, the interest on renewable energy was feeble. However, the increase in the level of air pollution and environmental degradation of fossil fuel burning has created more interest on renewable energy investments (Doukas et al. [1]). Electricity consumption in GCC countries increased rapidly during the last three decades not only in absolute terms, but also in terms of its share in total energy demand. The continued growth in electricity demand will require significant investments over the coming period and will put further strains on government budgets (Al-Faris, [2]). Due to the vast growth of development in the infrastructure and investment in energy, the electricity consumption in the GCC countries had increased at a fast rate (Al-Naser and Al-Naser [3]); 12.4\% from 2005 to 2009 (3.15\%, annually). This rate is much larger than the world average, which is $2.2 \%$ for the same period, or USA (0.5\%). In 2005, the average Watt per person in the GCC countries was 1149 which is much higher than the world average (297 W per person) or the European Union ( $700 \mathrm{~W} /$ person) - but less than USA ( $1460 \mathrm{~W} /$ person). The GCC countries need to increase its electrical capacity by $60,000 \mathrm{MW}$, which represents $80 \%$ of the current installed capacity, to meet demand in 2015. This means that there is a need to build 50 more gas fired power generator plant turbine (each rated $1400 \mathrm{MW}$ ). Al-Naser and Al-Naser [3]) has also worked out the cost of power production in GCC countries from wind power plants. The cost of $1 \mathrm{kWh}$ from wind electricity in the GCC countries may be from US $₫ 10$ (large turbine $\approx 2 \mathrm{MW}$ at $80 \mathrm{~m}$ height with good wind speed) to US $₫ 15$ (for large turbine $\approx 2 \mathrm{MW}$ at $80 \mathrm{~m}$ height with modest wind speed) while the cost of $\mathrm{kWh}$ from grid connected Wind farm plant (20 MW) - with a cost of USD 38.6 million and energy-is US $₫ 6.7 / \mathrm{kWh}$ to US $₫$ $8.8 / \mathrm{kWh}$, depending on the location of wind farm. This makes it very challengeable for investor, government (Feed-in-Tariff) and citizens because each citizen in GCC countries pays only US cent 1 for each $\mathrm{kWh}$, for consumption less than $3000 \mathrm{kWh}$, or even nothing for citizens-like in Qatar. Institutes and researchers have carried out studies on feasibility/economics/environmental impacts/policies related to wind power plants in different GCC and MENA countries. Masdar Institute in Abu Dhabi has carried out many studies on the feasi- 
bility of different types of renewable energies in this region (Nader [4]; Reiche [5] and Janajreh et al. [6]).

Rehman et al. [7] has studied on the wind power cost at twenty locations in Saudi Arabia. Rehman and Ahmad [8] have studied the wind energy potential in the coastal areas of Saudi Arabia. Yanbo and Dhahran are identified as the best location. Further detailed studies for Yanbo location was carried out by Rehman [9]. The wind speed at this location is found to be more than $3.5 \mathrm{~m} / \mathrm{s}$ for $69 \%$ of the time in a year.

In Iran, Mostafaeipour [10] studied on the feasibility for offshore wind turbine installation compared to world. The investigation was carried out to harness wind power in the Arabian Gulf, Caspian Sea, Urmia Lake and Gulf of Oman. Development of renewable energy is one of priority research goals in Iran. There are many installed wind turbines in suitable regions like Manjil and Binalood in Iran, but there has not been any offshore wind installation yet in Iran. It is suggested that policy makers to invest and pay more attentions toward harnessing renewable energy sources like offshore wind in Arabian Gulf and Gulf of Oman in southern parts of Iran. Mostafaeipour et al. [11] has carried out detailed feasibility study for wind energy for the city of Shahrbabak in Iran. Similar study was carried out for the capital city, Tehran by Keyhani et al. [12]. Marafia and Ashour [13] have investigated on the economics of offshore and onshore wind energy systems in Qatar. The study result indicates the suitability of utilizing small to medium-size wind turbine generators, efficiently in the offshore since the average wind speed was more than $6.0 \mathrm{~m} / \mathrm{s}$. Oman also has carried out many investigations on the status and future prospectus of renewable energy (Kazem [14] and on wind power for a new city (Albadi et al. [15]). It is clear that most of the GCC countries have good offshore wind energy potential and there are tendencies to invest for commercial offshore wind mills.

It is clear from these studies that the countries around the Arabian Gulf have significant interest in exploiting the wind energy on the land and over the Arabian Gulf. However, a detailed knowledge of the wind power resource over the Arabian Gulf is missing. This is the main motivation for the present study. The results of this study will help the governments of different GCC countries for planning and implementation of wind power plants in their respective territorials waters in the Arabian Gulf.

A thorough knowledge of the statistical properties of the wind speed is essential for predicting the energy output of a wind energy conversion system. Because of the high variability in space and time of wind energy, it is important to verify that the analyzing method used for the wind data will yield the estimated energy of the wind speed distribution. The wind variation for a typical site is usually described using the so-called Weibull distribution. In this study, attention is given to the Weibull two parameter ( $k$, the shape parameter, and $c$, the scale parameter) functions because it has been found to fit a wide collection of wind speed data around the world. The main objectives of this study are to come up with wind energy map of Arabian Gulf based on statistical analysis of long 
term data. It is strongly hoped that this new wind energy map will have many potential uses including identification of the best location in the Arabian Gulf for installing offshore wind energy farms.

\section{Methodology and Analysis}

1) Wind Power density function: It is well known that the power of the wind at speed $v$ through a wind turbines blade sweep area $(A)$ increases as the cube of its velocity and can be calculated as follows (Ahmed [16], Al-Naser [17]):

$$
P(v)=\frac{1}{2} \rho A v^{3}
$$

where $\rho$ is the mean air density $\left(1.225 \mathrm{~kg} / \mathrm{m}^{3}\right.$ at average atmospheric pressure at sea level and at $15^{\circ} \mathrm{C}$ ). However, as a consequence of the cubic dependence of power with wind velocity, the mean speed remains an unsuitable measure when assessing the available wind power density.

It is also well known that the statistical behavior of the wind can be approximated by the Weibull distribution function (Weibull [18], Ramrez [19] and Celik [20]), which describes the probability, $P(w)$, for a certain wind speed, $V$, depending on the scale parameter, $c$, and the shape parameter, $k$. The expected monthly or annual wind power density per unit area of a site based on a Weibull probability density function can be expressed as follows:

$$
P_{w}=\frac{1}{2} \rho c^{3} \neg\left[1+\frac{3}{k}\right]
$$

To following equation is used to calculate the Weibull shape parameter or factor $(k)$ by iteration method (maximum likelihood method):

$$
k=\left(\frac{\sum_{1}^{n} v^{k} \operatorname{Ln}(v)}{\sum_{1}^{n} v^{k}}-\frac{\sum_{1}^{n} \operatorname{Ln}(v)}{n}\right)^{-1}
$$

where $c$ is the Weibull scale parameter $(\mathrm{m} / \mathrm{s})$, and is given by:

$$
c=\frac{v_{m}}{\neg\left(1+\frac{1}{k}\right)}
$$

where $\neg$ the gamma function and " $n$ " is is the total wind data record. Then, Weibull scale parameter is calculated as

$$
c=\left(\frac{\sum_{1}^{n} v^{k}}{n}\right)^{\frac{1}{k}}
$$

The two significant parameters $k$ and $c$ are closely related to the mean value of the wind speed $V_{m}$ (Celik [21]). By extracting $c$ from Equation [3] and $k$, the power density for the Rayleigh model can be found by (Al-Mohamad [22]):

$$
P_{R}=\frac{3}{\pi} \rho c^{3}\left(\frac{\pi}{4}\right)^{\frac{3}{2}}
$$


Errors in calculating the power densities using the distributions in comparison to values of the probability density distributions derived from measured wind speed values can be found by the following Equation:

$$
\operatorname{Error}(\%)=\frac{P_{W, R}-P_{m, R}}{P_{m, R}}
$$

where $P_{W, R}$ is the mean power density calculated from either the Weibull or Rayleigh function used in the calculation of the error and $P_{m, R}$ is the wind power density assessed from the probability density distribution, derived from the measured wind speed values which serves as the reference mean power density.

2) Wind speed variation with height: Since the wind speed data are available at 1 height of $10 \mathrm{~m}$ from the ground or mean water level, it is necessary to assess the wind speed at the center of turbine hub, which varies from $30 \mathrm{~m}$ to $50 \mathrm{~m}$ depends on its capacity. This requires an equation that predicts the wind speed at one height in terms of the measured speed at another height. The most common expression for the variation of wind speed with height is the power law (Perez [23]) having the following form:

$$
\frac{v_{2}}{v_{1}}=\left[\frac{h_{2}}{h_{1}}\right]^{\infty}
$$

where $v_{1}$ and $v_{2}$ are the mean wind speeds at heights $h_{1}$ and $h_{2}$, respectively. The exponent $\propto$ depends on factors such as surface roughness and atmospheric stability as shown in Table 1 .

Numerically, it lies in the range $0.0-0.5$, with the most frequently adopted roughness value being 0.5 with roughness length of 0.0024 .

The Equation (6) can be written as follows:

$$
\frac{v_{2}}{v_{1}}=\frac{\ln \left(\frac{h_{2}}{r}\right)}{\ln \left(\frac{h_{1}}{r}\right)}
$$

where $r$ is Roughness Length $(\mathrm{m}), V_{2}$ wind speeds at selected elevation from ground level $h_{2}$.

The wind speed at a certain height above ground level is

$$
v_{2}=v_{1}\left[\frac{\ln \left(\frac{h_{2}}{r}\right)}{\ln \left(\frac{h_{1}}{r}\right)}\right]
$$

The fact that the wind profile is twisted towards a lower speed as we move closer to ground level is usually called wind shear. Wind shear may also be important when designing wind turbines.

The information provided in this methodology section is used for assessing the Weibull parameters over the Arabian Gulf and its probability distribution. 
Table 1. Roughness classes and roughness length (Source: definitions according to the European Wind Atlas, WASP).

\begin{tabular}{|c|c|c|c|}
\hline Roughness & $\begin{array}{l}\text { Roughness } \\
\text { Length m }\end{array}$ & $\begin{array}{c}\text { Energy } \\
\text { Index \% }\end{array}$ & Landscape Type \\
\hline 0 & 0.0002 & 100 & Water surface \\
\hline 0.5 & 0.0024 & 73 & $\begin{array}{l}\text { Completely open terrain with a smooth } \\
\text { surface, e.g. concrete runways in } \\
\text { airports, mowed grass, etc. }\end{array}$ \\
\hline 1 & 0.03 & 52 & $\begin{array}{l}\text { Open agricultural area without fences and } \\
\text { hedgerows and very scattered buildings. } \\
\text { Only softly rounded hills }\end{array}$ \\
\hline 1.5 & 0.055 & 45 & $\begin{array}{c}\text { Agricultural land with some houses and } 8 \\
\text { meter tall sheltering hedgerows with a distance } \\
\text { of approx. } 1250 \text { meters }\end{array}$ \\
\hline 2 & 0.1 & 39 & $\begin{array}{l}\text { Agricultural land with some houses and } 8 \\
\text { meter tall sheltering hedgerows with a } \\
\text { distance of approx. } 500 \text { meters }\end{array}$ \\
\hline 2.5 & 0.2 & 31 & $\begin{array}{l}\text { Agricultural land with many houses, shrubs } \\
\text { and plants, or } 8 \text { meter tall sheltering hedgerows } \\
\text { with a distance of approx. } 250 \text { meters }\end{array}$ \\
\hline 3 & 0.4 & 24 & $\begin{array}{l}\text { Villages, small towns, agricultural land with } \\
\text { many or tall sheltering hedgerows, forests and } \\
\text { very rough and uneven terrain }\end{array}$ \\
\hline 3.5 & 0.8 & 18 & Larger cities with tall buildings \\
\hline
\end{tabular}

\section{Results and Discussions}

Data for wind speed used in the present calculations were obtained for the period 1979-2015 from the Coastal Information System Database at KISR (Al-Salem [24] [25] and Rakha [26]). The wind data used were numerically predicted and are validated with the instrumentally measured wind speed data from Kuwait International Airport data (Al-Salem [27]). All the locations in the study were positioned over Arabian Gulf waters in open spaces free of obstacles at a height of $10 \mathrm{~m}$ above the ground. Wind speeds stored and averaged over one hour in the database. The wind speed changes with height because air pressure is low at higher elevations and the air which gets heated from the surface of earth also moves to higher altitude. This air provides energy to the air speed at higher elevation. In this study, 3 different heights at 10,30 and $50 \mathrm{~m}$ from the sea level are used to calculate the mean wind speed maps over Arabian Gulf waters for a period of 1979-2015 as shown in Figure 3. The results obtained from the wind speed study can be summarized as follows:

- The central $\mathrm{n}$ area of Arabian Gulf has higher wind speed ranging from 6 - 8 $\mathrm{m} / \mathrm{s}$ at $10 \mathrm{~m}$ elevation, $7-8 \mathrm{~m} / \mathrm{s}$ for $30 \mathrm{~m}$ elevation and $8-9 \mathrm{~m} / \mathrm{s}$ for $50 \mathrm{~m}$ elevation.

- The northern area of Arabian Gulf has moderate wind speed ranging from 3 4 at $10 \mathrm{~m}$ elevation, $4-5 \mathrm{~m} / \mathrm{s}$ for $30 \mathrm{~m}$ elevation and $5-6 \mathrm{~m} / \mathrm{s}$ for $50 \mathrm{~m}$ elevation. 

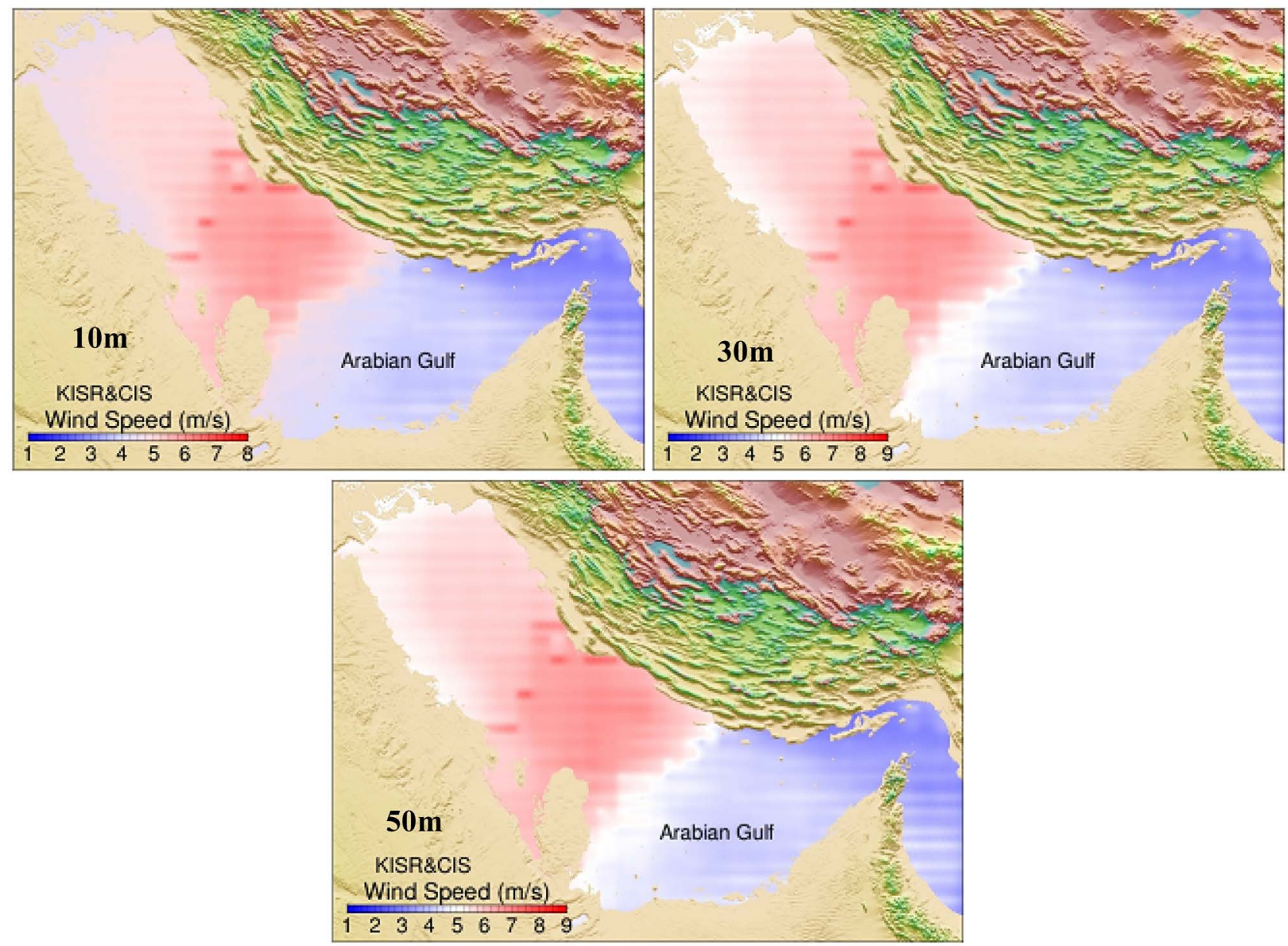

Figure 3. Mean wind speed (m/s) at 10, 30 and $50 \mathrm{~m}$ above sea level over. Arabian Gulf waters for periods of 1979-2015.

- The southern area of Arabian Gulf has low wind speed ranging from 2.5 - 3.0 $\mathrm{m} / \mathrm{s}$ for $10 \mathrm{~m}$ elevation, $3-4 \mathrm{~m} / \mathrm{s}$ for $30 \mathrm{~m}$ elevation and $4-4.5 \mathrm{~m} / \mathrm{s}$ for $50 \mathrm{~m}$ elevation.

Hence it is clear that the central area of the Arabian Gulf is attractive for extracting wind energy.

The variation of wind velocity is often described by using the Weibull two-parameter density function. As described earlier, the Weibull shape function $k$ and scale factor $c$ are calculated analytically from the available data and are presented as a maps of mean values in Figure 4 for sea level elevations at 10, 30 and $50 \mathrm{~m}$ over Arabian Gulf waters. At the central area of Arabian Gulf, the scale parameter $c$ has higher prediction value and is ranging from $6-8 \mathrm{~m} / \mathrm{s}$ for $10 \mathrm{~m}$ elevation, $7-8 \mathrm{~m} / \mathrm{s}$ for $30 \mathrm{~m}$ elevation and $8-9 \mathrm{~m} / \mathrm{s}$ for $50 \mathrm{~m}$ above sea level. The Weibull shape parameter $k$ is found to vary from $2.5-3$ at the north and central area of the Arabian Gulf. This shows the Weibull distribution function has a good wind speed predicted comparing to the mean wind speed shown in Figure 3 for all elevation selected.

The average annual maps of wind power densities were calculated from CIS wind speed database and from Weibull distribution prediction are shown in 

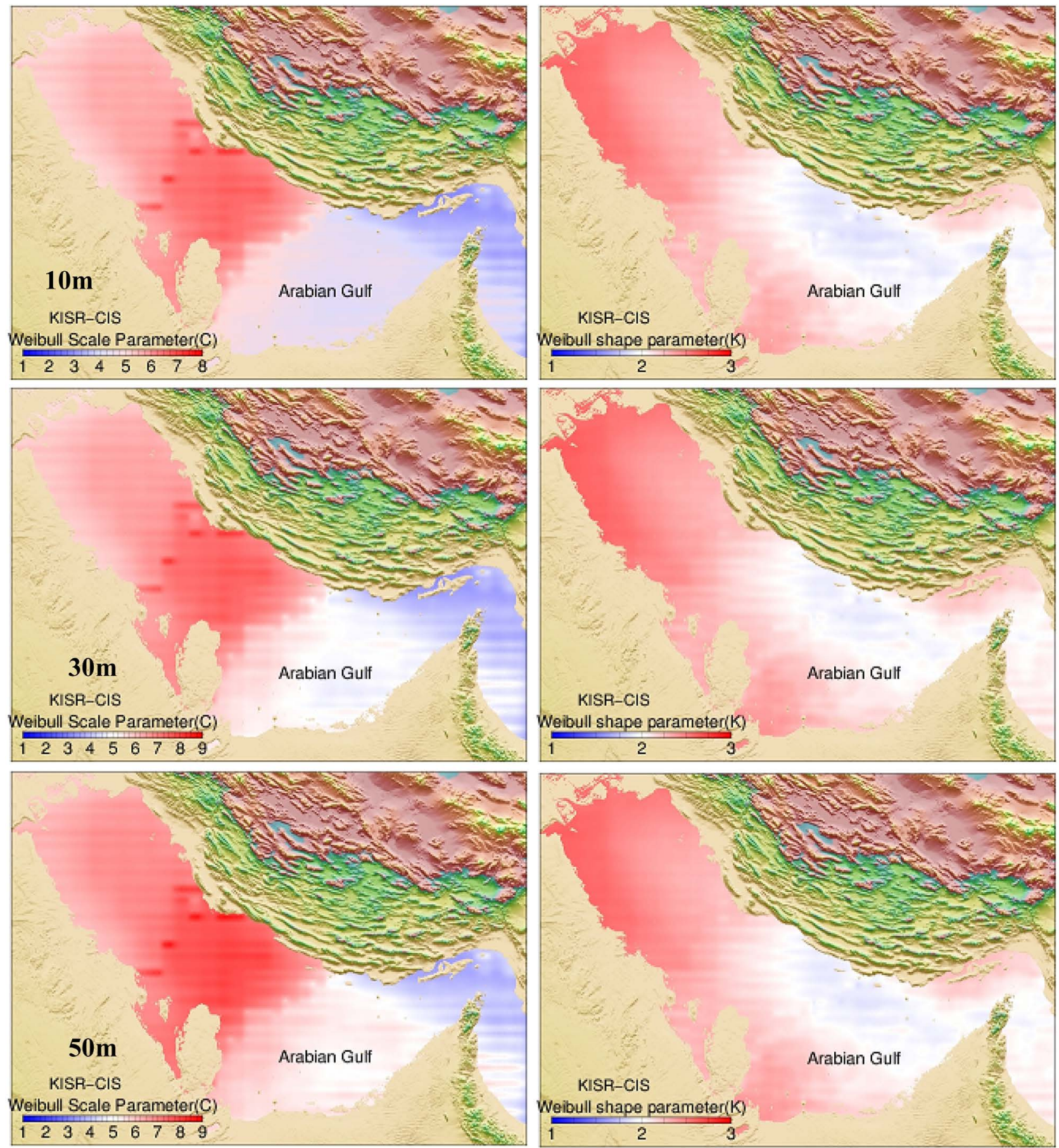

Figure 4. Weibull shape function $k$ and scale factor $c$ for wind speed data at 10, 30 and $50 \mathrm{~m}$ above sea level over Arabian Gulf waters for periods of $1979-2015$.

Figure 5 for elevation 10, 30, $50 \mathrm{~m}$ above sea level over Arabian Gulf waters for period of 1979-2015. The information gathered from this figure is as follows:

- The wind power density over Arabian Gulf Waters is the highest in the central region of the Gulf. The power density at $10 \mathrm{~m}$ hub height varies between 200 to $300 \mathrm{w} / \mathrm{m}^{2}$; at $30 \mathrm{~m}$, it varies between 200 to $300 \mathrm{w} / \mathrm{m}^{2}$ and at $50 \mathrm{~m}$, it is more than $300 \mathrm{w} / \mathrm{m}^{2}$. 

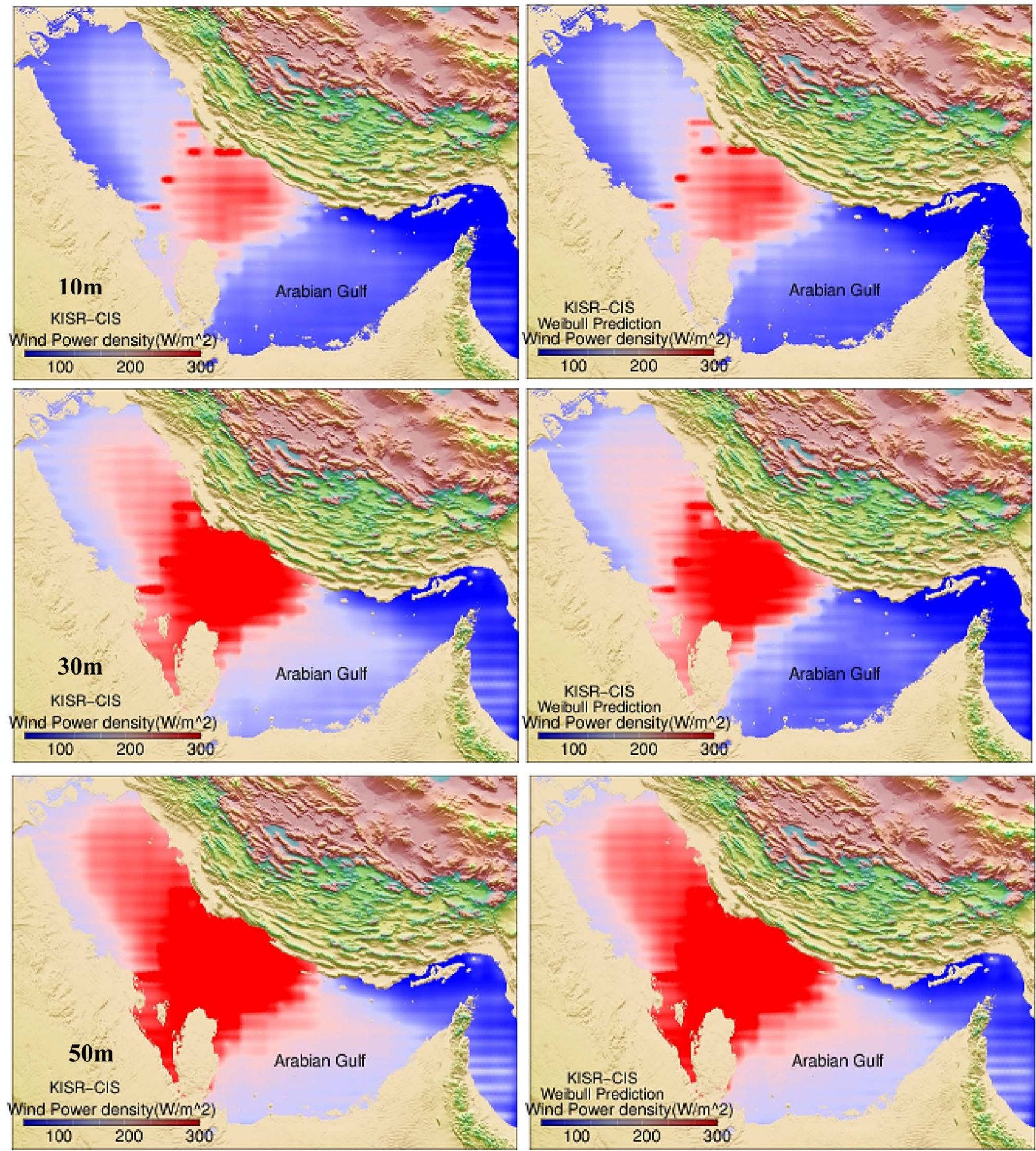

Figure 5. Comparison of Weibull predicted and actual distribution of wind power density $\left(\mathrm{w} / \mathrm{m}^{2}\right)$ at 10,30 and $50 \mathrm{~m}$ over Arabian Gulf Waters for periods of (1979-2015).

- The wind power density over the southern region of the Arabian Gulf is the lowest. The wind power density at $10 \mathrm{~m}$ hub height is found to vary between 100 to $120 \mathrm{w} / \mathrm{m}^{2}$; at $30 \mathrm{~m}$, it varies between 120 to $150 \mathrm{w} / \mathrm{m}^{2}$ and at $50 \mathrm{~m}$, it is found to vary between 150 to $200 \mathrm{w} / \mathrm{m}^{2}$.

- In the northern region of the Arabian Gulf, the wind power density at $10 \mathrm{~m}$, 
$30 \mathrm{~m}$ ad $50 \mathrm{~m}$ hub heights vary between 100 to $170 \mathrm{w} / \mathrm{m}^{2}, 180$ to $190 \mathrm{w} / \mathrm{m}^{2}$ and 200 to $220 \mathrm{w} / \mathrm{m}^{2}$ respectively

Figure 5 is provided to show how the predicted wind power density by Weibull distribution and actually estimated value from the data is comparing. It is found that at elevation of $30 \mathrm{~m}$ or $50 \mathrm{~m}$ and at central region of the Arabian Gulf, the wind power is attractive and is lying in Class 2 as shown Table 2 of the Wind Energy Resource Atlas of the United States (Elliott [28]). Wind mills of larger capacities can be installed in this region. Similarly, at elevations of $30 \mathrm{~m}$ or $50 \mathrm{~m}$ at North or south region of Arabian Gulf waters, small-scale wind power plants can be installed since this regions falls under Class 1 of Table 2.

The annual average wind power density maps of the whole Arabian Gulf are displayed at Figure 4 and Figure 5. However, a monthly wind power distribution is needed for monthly power generation estimate. Figure 6 and Figure 7 provides the monthly average wind power density maps for January to June and July to December respectively over Arabian Gulf waters at hub height of 30.

It is clear that Figure 6 and Figure 7 provides the following vital information of monthly and season distribution of wind power:

- During the winter season (December-February), the wind power is high at central region of Arabian Gulf and moderate at both north and southern region.

- During spring season (March-May), the wind power is high at central region of Arabian Gulf, moderately high at north, but low at southern region.

- During summer season (June-August), the wind power is high at central and northern regions of Arabian Gulf and moderate in the southern region. However, during August, the wind power density becomes low over the whole Arabia Gulf waters.

- During the fall season (September-November), the wind power is low at all the regions over Arabian Gulf waters; but in November the wind power become high at the central.

It is to be noted that the power consumption is high during summer due to powering for air conditioning and hence, the high wind power availability at the central and northern Arabian Gulf region is attractive for countries around these regions. Table 3 shows the mean monthly wind power density at elevation of $30 \mathrm{~m}$ for a selected location over the Arabian Gulf waters for period of

Table 2. Wind power class (Source: Wind power class 2014 [29]).

\begin{tabular}{cccc}
\hline Wind Power Class & Wind Speed $(\mathrm{m} / \mathrm{s})$ & WPD $\left(\mathrm{w} / \mathrm{m}^{2}\right)$ & Resource Potential \\
\hline 1 & $0-4.9$ & $0-243$ & Not suitable \\
2 & $4.9-6.9$ & $243-378$ & Marginal \\
3 & $6.9-7.5$ & $378-500$ & Fair \\
4 & $7.5-8.1$ & $500-616$ & Good \\
5 & $8.1-8.6$ & $616-748$ & Excellent \\
6 & $8.6-9.4$ & $748-978$ & Outstanding \\
\hline
\end{tabular}


Table 3. Monthly mean wind power densities $\left(\mathrm{w} / \mathrm{m}^{2}\right)$ for period of $1979-2015$ for selected locations in the Arabian Gulf at hub height of $30 \mathrm{~m}$ above sea level.

\begin{tabular}{|c|c|c|c|c|c|}
\hline & $\begin{array}{c}\text { Kuwait } \\
\text { E48 } 18^{\circ} 0.0^{\prime \prime} \\
\mathrm{N} 29^{\circ} 12^{\prime} 0.0^{\prime \prime}\end{array}$ & $\begin{array}{l}\text { Saudi Arabia } \\
\text { E50 } 30^{\circ} 0^{\prime \prime} \\
\mathrm{N} 26^{\circ} 36^{\prime} 0.0^{\prime \prime}\end{array}$ & $\begin{array}{c}\text { Bahrain } \\
\text { E504 } 48^{\prime} 0.0^{\prime \prime} \\
\text { N26 } 18^{\prime} 0.0^{\prime \prime}\end{array}$ & $\begin{array}{c}\text { Qatar } \\
\text { E51 } 18^{\circ} 0.0^{\prime \prime} \\
\text { N26 } 12^{\circ} 0.0^{\prime \prime}\end{array}$ & $\begin{array}{l}\text { Unit Arab } \\
\text { Emirate } \\
\text { E54 } 48^{\prime} 0 . " \\
\mathrm{~N} 25^{\circ} 00^{\prime} 0.0^{\prime \prime}\end{array}$ \\
\hline January & 141 & 349 & 385 & 329 & 138 \\
\hline February & 175 & 381 & 428 & 389 & 168 \\
\hline March & 175 & 326 & 356 & 348 & 176 \\
\hline April & 156 & 233 & 247 & 240 & 151 \\
\hline May & 157 & 255 & 282 & 296 & 160 \\
\hline Jun & 259 & 405 & 428 & 378 & 115 \\
\hline July & 233 & 272 & 276 & 264 & 110 \\
\hline August & 167 & 184 & 188 & 169 & 77 \\
\hline September & 125 & 154 & 163 & 143 & 71 \\
\hline October & 101 & 166 & 179 & 161 & 64 \\
\hline November & 124 & 279 & 310 & 276 & 107 \\
\hline December & 139 & 329 & 357 & 297 & 113 \\
\hline
\end{tabular}
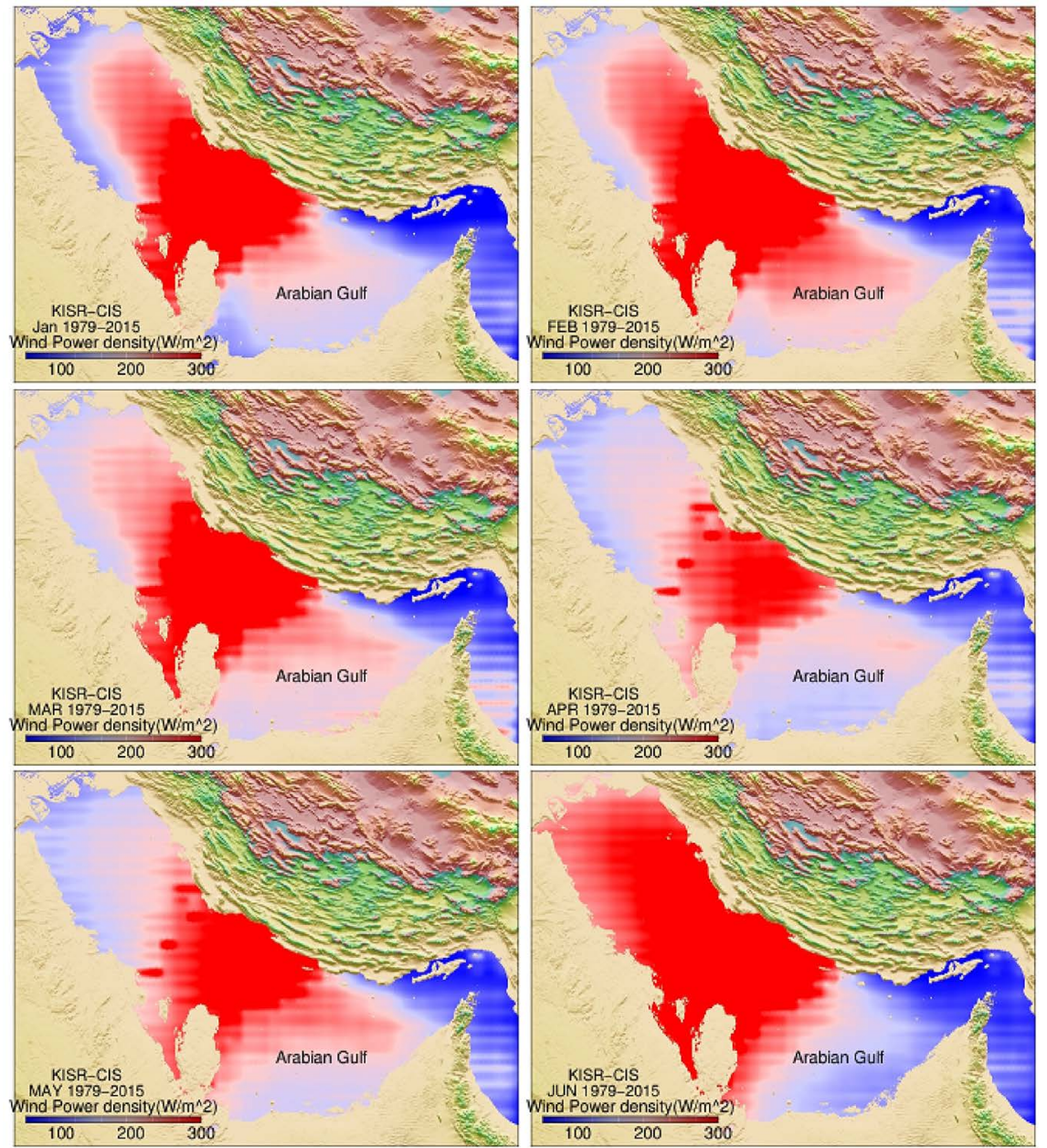

Figure 6. Monthly distribution of wind power density $\left(\mathrm{w} / \mathrm{m}^{2}\right)$ at $30 \mathrm{~m}$ over Arabian Gulf Waters for periods of (1979-2015) for January to June. 

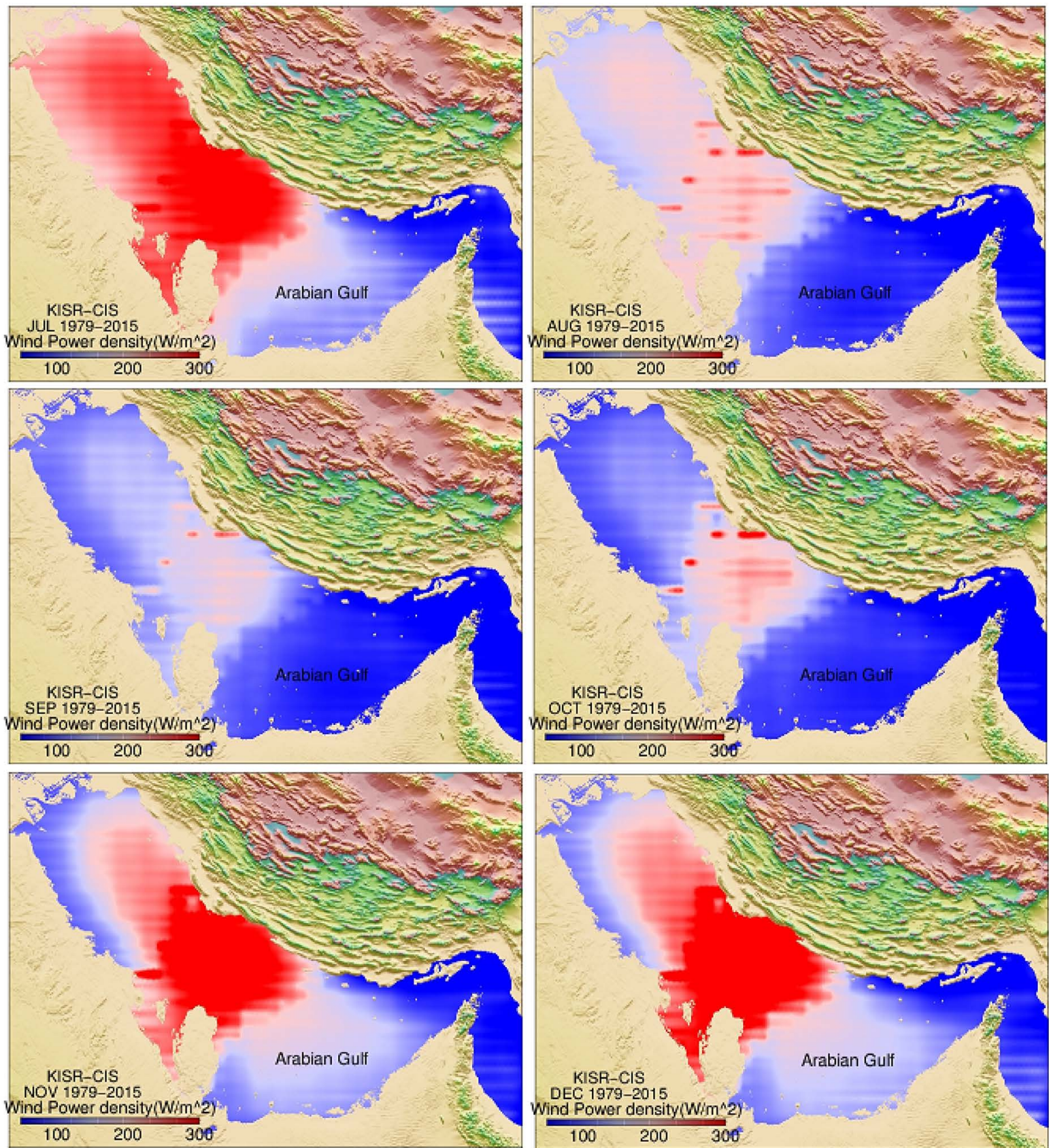

Figure 7. Monthly distribution of wind power density $\left(\mathrm{w} / \mathrm{m}^{2}\right)$ at $30 \mathrm{~m}$ over Arabian Gulf Waters for periods of (1979-2015) for July to December.

1979-2015. According to this table, the central region of the Arabian Gulf (Saudi Arabia, Bahrain and Qatar) has a good wind power regime for economical installation of large-scale wind power production, lying in Class 2 as shown in Table 2. However, the wind power potential is low during September and October.

\section{Assessment of Wind Power Density Potential at G.C.C Countries}

The Interest in renewable energy in the GCC countries has been on the rise in 
recent years. With the region's consumption expected to continue growing at a fast pace over the next two decades, renewable energy have become an important consideration in government strategies to diversify the domestic energy mix. The renewable energy could also help mitigate the natural gas shortages GCC economies could experience over the coming decades. In Kuwait, Saudi Arabia and the UAE, local production has already been outstripped by domestic market consumption. To examine the wind power potential of the GCC countries over their territorial waters in Arabian Gulf, Table 4 is provided.

- Countries, which are located at the central zone of Arabian Gulf waters (such as Saudi Arabia, Bahrain and Qatar) have annual wind power of 277, 300, 275 $\mathrm{w} / \mathrm{m}^{2}$, respectively. This order of wind power is attractive for large-scale power production, lying in Class 2 of the US wind power density classification (Elliott [28]).

- Countries located at the South zone of Arabian Gulf waters (United Arab Emirate) have annual wind power of $120 \mathrm{w} / \mathrm{m}^{2}$, which is low for economic large-scale power production.

- Countries located at the north zone of Arabian Gulf waters (Kuwait) have annual wind power of $166 \mathrm{w} / \mathrm{m}^{2}$, which is acceptable for economical medium-scale power production.

It is important to compare the probability distribution of the wind power assessed based on the data and derived from Weibull distribution to assess how good Weibull distribution is for the present study. Figure 8 shows such plot. It is found that the prediction by Weibull distribution compares satisfactorily with the estimate of the actual data for the locations indicated in Table 4.

\section{Conclusions}

The potential of wind energy resource over Arabian Gulf waters, covering 2300 grid points is carried out using data available with Coastal Information System

Table 4. Mean wind power densities $\left(\mathrm{w} / \mathrm{m}^{2}\right)$ for period of 1979-2015 over Arabian Gulf waters at hub height of $30 \mathrm{~m}$ above sea level for GCC countries.

\begin{tabular}{|c|c|c|c|}
\hline $\begin{array}{l}\text { G.C.C. } \\
\text { Countries }\end{array}$ & $\begin{array}{c}\text { Map } \\
\text { Location }\end{array}$ & $\begin{array}{c}\text { Mean Annual WPD } \\
\mathrm{w} / \mathrm{m}^{2}\end{array}$ & $\begin{array}{c}\text { Total Annual } \\
\text { Energy }(8760 \mathrm{hr}) \\
\mathrm{w} / \mathrm{m}^{2}\end{array}$ \\
\hline Kuwait & $\begin{array}{l}\mathrm{E} 48^{\circ} 18^{\prime} 0.0^{\prime \prime} \\
\mathrm{N} 29^{\circ} 12^{\prime} 0.0^{\prime \prime}\end{array}$ & 166 & 1454 \\
\hline Saudi Arabia & $\begin{array}{l}\mathrm{E} 50^{\circ} 30^{\prime} 0.0^{\prime \prime} \\
\mathrm{N} 26^{\circ} 36^{\prime} 0.0^{\prime \prime}\end{array}$ & 277 & 2426 \\
\hline Bahrain & $\begin{array}{l}\text { E50 } 28^{\prime} 0.0^{\prime \prime} \\
\text { N26 } 18^{\prime} 0.0^{\prime \prime}\end{array}$ & 300 & 2628 \\
\hline Qatar & $\begin{array}{l}\text { E51 } 18^{\prime} 0.0^{\prime \prime} \\
\text { N26 } 12^{\prime} 0.0^{\prime \prime}\end{array}$ & 275 & 2409 \\
\hline Unit Arab Emirate & $\begin{array}{l}\mathrm{E} 54^{\circ} 48^{\prime} 0.0^{\prime \prime} \\
\mathrm{N} 25^{\circ} 00^{\prime} 0.0^{\prime \prime}\end{array}$ & 120 & 1051 \\
\hline
\end{tabular}




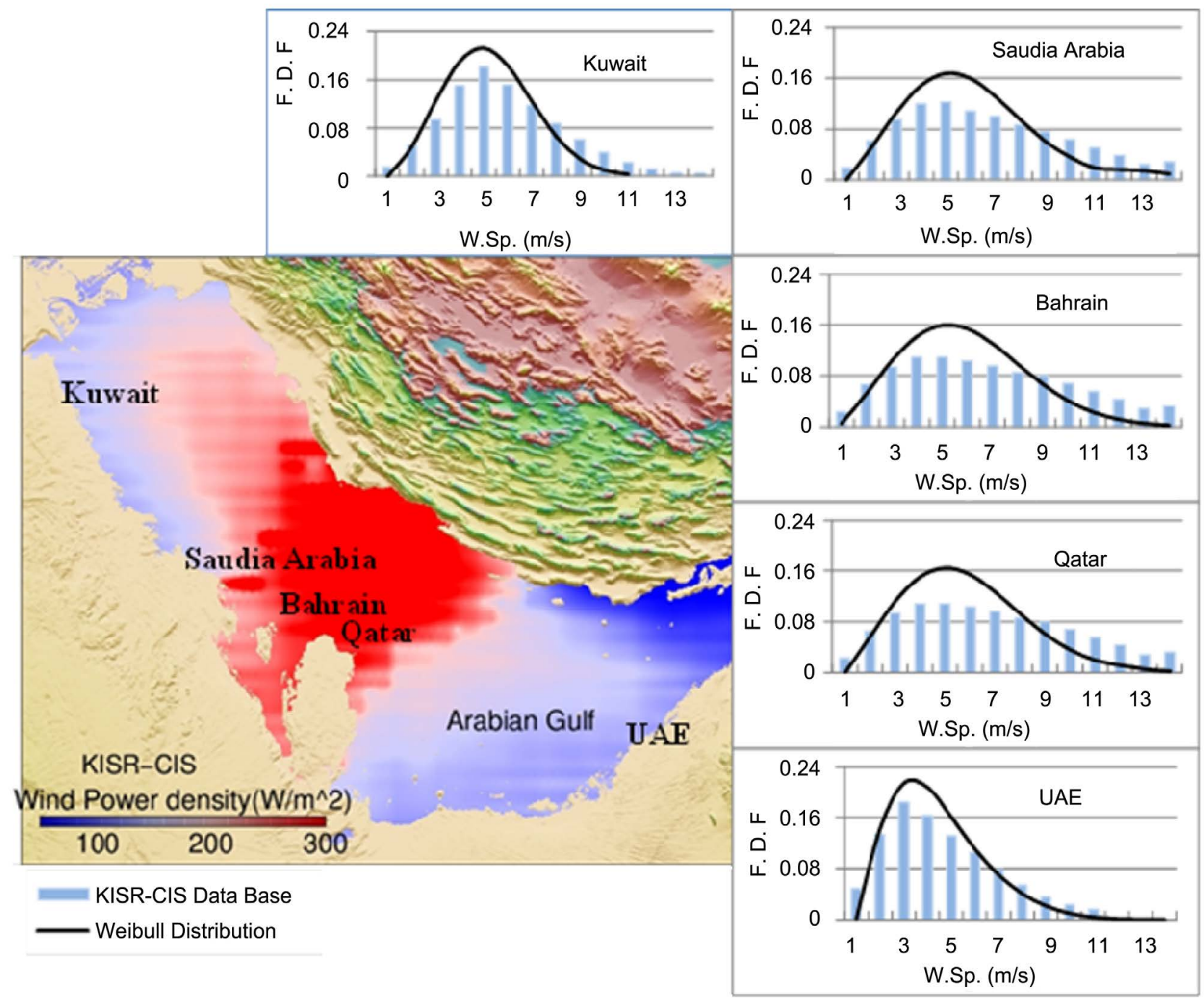

Figure 8. Comparison of the probability distribution function (PDF) of wind speeds derived from CIS database data at Elevation $30 \mathrm{~m}$ above sea level with Weibull distribution for periods 1979-2015 for G.C.C. countries.

(CIS) data base from 1979 to 2015 . The probability density and power density were derived from these data. Weibull probability density function has been fitted to the wind speed data and the wind power density was evaluated. The study is carried out at $10 \mathrm{~m}, 30 \mathrm{~m}$ and $50 \mathrm{~m}$ elevations. The most important conclusions of this study are summarized as follows:

- The central location of the Arabian Gulf has higher annual average wind speed, ranging from $6-8 \mathrm{~m} / \mathrm{s}$ at $10 \mathrm{~m}$ elevation, $7-8 \mathrm{~m} / \mathrm{s}$ at $30 \mathrm{~m}$ elevation and $8-9 \mathrm{~m} / \mathrm{s}$ at $50 \mathrm{~m}$ elevation.

- The scale parameter $\mathrm{c}$ at central location of Arabian Gulf is found to range from $6-8 \mathrm{~m} / \mathrm{s}$ for $10 \mathrm{~m}$ elevation, $7-8 \mathrm{~m} / \mathrm{s}$ for $30 \mathrm{~m}$ elevation and $8-9 \mathrm{~m} / \mathrm{s}$ for $50 \mathrm{~m}$ above sea level.

- The Weibull shape parameter $\mathrm{k}$ varies from 2.5 - 3 at the north and central of the Arabian Gulf.

- The annual mean wind power density over Arabian Gulf Waters is the high- 
est in the central region of the Gulf. The power density at $10 \mathrm{~m}, 30 \mathrm{~m}$ and 50 $\mathrm{m}$ hub height varies between 200 to $300 \mathrm{w} / \mathrm{m}^{2}, 200$ to $300 \mathrm{w} / \mathrm{m}^{2}$ and more than $300 \mathrm{w} / \mathrm{m}^{2}$ respectively.

- It is attractive to install large scale wind power generation at the central region of the Arabian Gulf and at elevations of $30 \mathrm{~m}$ or $50 \mathrm{~m}$, since this region lies in Class 2 category of the Wind Energy Resource Atlas of the United States (Elliott [28]).

- The wind power density is attractive especially in summer season around the central region location in Arabian Gulf (Saudi Arabia, Bahrain and Qatar).

\section{References}

[1] Doukas, H., Patlitzianas, H.D., Kagiannas, A.G. and Psarras, J. (2006) Sources and Rationale Use of Energy Development in the Countries of GCC: Myth or Reality? Renewable Energy, 31, 755-770. https://doi.org/10.1016/j.renene.2005.05.010

[2] Al-Faris, A.R.F. (2002) The Demand for Electricity in the GCC Countries. Energy Policy, 30, 117-124. https://doi.org/10.1016/S0301-4215(01)00064-7

[3] Al-Naser, W.E. and Al-Naser, N.W. (2011) The Status of Renewable Energy in the GCC Countries. Renewable and Sustainable Energy Reviews, 15, 3074-3098. https://doi.org/10.1016/j.rser.2011.03.021

[4] Nader, S. (2009) Paths to a Low-Carbon Economy-The Masdar Example. Energy Procedia, 1, 3951-3958. https://doi.org/10.1016/j.egypro.2009.02.199

[5] Reiche, D. (2010) Renewable Energy Policies in the Gulf Countries: A Case Study of the Carbon-Neutral "Masdar City" in Abu Dhabi. Energy Policy, 38, 378-382. https://doi.org/10.1016/j.enpol.2009.09.028

[6] Janajreh, I., Su, L. and Alan, F. (2013) Wind Energy Assessment: Masdar City Case Study. Renewable Energy, 52, 8-15. https://doi.org/10.1016/j.renene.2012.09.025

[7] Rehman, S., Halawani, T.O. and Mohandes, M. (2003) Wind Power Cost Assessment at Twenty Locations in the Kingdom of Saudi Arabia. Renewable Energy, 28, 573-583. https://doi.org/10.1016/S0960-1481(02)00063-0

[8] Rehman, S. and Ahmad, A. (2004) Assessment of Wind Energy Potential for Coastal Locations of the Kingdom of Saudi Arabia. Energy, 29, 1105-1115. https://doi.org/10.1016/j.energy.2004.02.026

[9] Rehman, S. (2004) Wind Energy Resources Assessment for Yanbo, Saudi Arabia. Energy Conversion and Management, 15, 2019-2032. https://doi.org/10.1016/j.enconman.2003.11.009

[10] Mostafaeipour, A., Sedaghat, A., Dehghan-Niri, A.A. and Kalantar, V. (2011) Wind Energy Feasibility Study for City of Shahrbabak in Iran. Renewable and Sustainable Energy Reviews, 15, 2545-2556. https://doi.org/10.1016/j.rser.2011.02.030

[11] Keyhani, A., Varnamkhasti, M.G., Khanali, M. and Abbaszadeh, R. (2010) An Assessment of Wind Energy Potential as a Power Generation Source in the Capital of Iran, Tehran. Energy, 35, 188-201. https://doi.org/10.1016/j.energy.2009.09.009

[12] Mostafaeipour, A. (2010) Feasibility Study of Offshore Wind Turbine Installation in Iran Compared with the World. Renewable and Sustainable Energy Reviews, 14, 1722-1743. https://doi.org/10.1016/j.rser.2010.03.032

[13] Marafia, A.H. and Ashour, H.A. (2003) Economics of Off-Shore/On-Shore Wind Energy Systems in Qatar. Renewable Energy, 28, 1953-1963. https://doi.org/10.1016/S0960-1481(03)00060-0 
[14] Kazem, H.A. (2011) Renewable Energy in Oman: Status and Future Prospects. Renewable and Sustainable Energy Reviews, 15, 3465-3469. https://doi.org/10.1016/j.rser.2011.05.015

[15] Albadi, M.H., El-Saadany, E.F. and Albadi, H.A. (2009) Wind to Power a New City in Oman. Energy, 34, 1579-1586. https://doi.org/10.1016/j.energy.2009.07.003

[16] Ahmed Shata, A.S. and Hanitsch, R. (2005) Evaluation of Wind Energy Potential and Electricity Generation on the Coast of Mediterranean Sea in Egypt. Renewable Energy, 31, 1183-1202. https://doi.org/10.1016/j.renene.2005.06.015

[17] Al-Nassar, W., Alhajraf, S.A., Al-Enizi, A. and Al-Awadhi, L. (2005) Potential Wind Power Generation in the State of Kuwait. Renewable Energy, 30, 2149-2161. https://doi.org/10.1016/j.renene.2005.01.002

[18] Weibull, W. (1951) Statistical Distributions Function of Wide Applicability. Journal of Applied Mechanics, 18, 293-297.

[19] Ramrez, P. and Carta, J.A. (2005) The Use of Wind Probability Distributions Derived from the Maximum Entropy Principle in the Analysis of Wind Energy. A Case Study. Energy Conversion and Management, 47, 2564-2577. https://doi.org/10.1016/j.enconman.2005.10.027

[20] Celik, A.N. (2004) On the Distributional Parameters Used in Assessment of the Suitability of Wind Speed Probability Density Functions. Energy Conversion and Management, 45, 1735-1747. https://doi.org/10.1016/j.enconman.2003.09.027

[21] Celik, A.N. (2003) A Statistical Analysis of Wind Power Density Based on the Weibull and Rayleigh Models at the Southern Region of Turkey. Renewable Energy, 29, 593-604. https://doi.org/10.1016/j.renene.2003.07.002

[22] Al-Mohamad, A. and Karmeh, H. (2003) Wind Energy Potential in Syria. Renewable Energy, 28, 1039-1046. https://doi.org/10.1016/S0960-1481(02)00186-6

[23] Perez, I.A., Garcia, M.A., Sanchez, M.L. and Torre de, B. (2004) Analysis of Height Variations of Sodar-Derived Wind Speeds in Northern Spain. Journal of Wind Engineering and Industrial Aerodynamics, 92, 875-894. https://doi.org/10.1016/j.jweia.2004.05.002

[24] Al-Salem, K. (2008) Interactive Coastal Information System for Kuwait's Territorial Waters Phase II: Website Site for Online Hydrodynamic Predictions. Kuwait Institute for Scientific Research, Report KISR 9485 Kuwait 2008.

[25] Al-Salem, K. and Al-Rashed, A. (2016) Updating the Database of KISR's Coastal Information System (CIS) by Using Numerical Techniques. Kuwait Institute for Scientific Research, Report KISR 13793, Kuwait 2016.

[26] Rakha, K. and Al-Salem, K. (2007) Interactive Coastal Information System for Kuwait's Territorial Waters Phase I: Hindcast of Wave, Water Levels and Current. Kuwait Institute for Scientific Research (EC026C) Kuwait 2007.

[27] Al-Salem, K. and Rakha, K. (2005) Verification of a WAM Model for the Arabian Gulf. Arabian Coast 2005 Conference, Dubai, 15 October 2005.

[28] Elliott, D. (1986) Wind Energy Resource Atlas of the United States. http://rredc.nrel.gov/wind/pubs/atlas/

[29] Wind Power Class (2014) Wind Energy Resource Atlas of the United States. http://rredc.nrel.gov/wind/pubs/atlas/tables/1-1T.html 